\title{
Isolation, Molecular Characterization and Insight into the Genome Sequence of E. coli Bacteriophage ADB-2 from Poultry Fecal Sample
}

\section{Bhensdadia DV 1 , Bhimani HD², Nathani NM², Rawal CM ${ }^{4}$, Koringa PG ${ }^{3}$, Joshi CG ${ }^{3}$, Kothari CR ${ }^{4}$ and Kothari RK ${ }^{1 *}$}

${ }^{1}$ Department of Microbiology, Christ College, Rajkot, Gujarat, India

${ }^{2}$ Department of Biosciences, Saurashtra University, Rajkot, Gujarat, India

${ }^{3}$ Department of Animal Biotechnology, College of Veterinary Science and Animal Husbandry, Anand Agricultural University, Anand, Gujarat, India

${ }^{4}$ Department of Biotechnology, Christ College, Rajkot, Gujarat, India

\begin{abstract}
Here we describe the isolation of few E. coli phages specifically ADB-2 and S. typhimurium bacteriophages from poultry fecal sample, its molecular characterization, genome sequencing and functional annotation. Escherichia phage ADB-2 was isolated from a chicken fecal sample. It is a virulent phage and shows effective inhibition of Escherichia coli strains. An antibiogram of the natural host of Escherichia phage ADB-2 showed that the host was sensitive against norfloxacin and gentamicin and that it demonstrated higher resistance against cotrimoxazole and oxytetracycline. The data generated from the genomic library contained 229,781 reads and $45,496,800$ nucleotide bases with an average read length of 198 bases. The assembly using Newbler version 2.6 generated a 50,552 bp long single chromosome. The genome annotation and comparative analysis of the genome using Rapid Annotation using Subsystem Technology showed that the phage genome comprised of $46 \%$ GC with 76 predicted coding regions and 2 RNA genes. The genome confirmed the presence of functional genes related to phage structure and packaging machinery, phage neck protein, tail structure for host interaction, phage DNA synthesis and host lysis. The complete genomic analysis of phage ADB-2 provides new insights into its characteristics and interactions with the host bacterium Escherichia coli. The complete genome sequence of the Escherichia phage ADB-2 genome can be accessed under the Gen Bank accession number JX912252.1.
\end{abstract}

Keywords: Drug resistant bacteria; Biosafety; Bacteriophage; Poultry fecal; Antibiogram; Whole Genome Sequencing; Annotation

\section{Introduction}

Escherichia coli and Salmonella have been recognized as zoonotic pathogens in animals and humans and are primary causes of reported food poisonings worldwide, with massive outbreaks occurring in recent years [1-3]. E. coli is found to be of economic significance in poultry causing chicken mortality [4]. Antibiotics are widely used to augment the development of animals in livestock husbandry. The use and exploitation of antibiotics in animals have led to appearance of resistant bacteria $[5,6]$, leading to concerns about the potential impact of antibiotic. Poultry meat is one of the most popular foods, often found to be contaminated with pathogenic bacteria. These infectious bacteria enter the human food chain through contamination of the environment via poultry products and fecal matter released by the infected chickens [7]. Conventional treatment of antibiotics has been reported less effective in recent years due to the emergence of antibiotic resistance in the causative agent [8]. Improvements in safety on poultry farms are becoming expensive and difficult [9], thereby leading to need to find a cost-effective way of preventing the infection of poultry with pathogenic bacteria [10]. Use of bacteriophages is gaining attention as an alternative method for preventing the bacterial contamination $[11,12]$. It is considered as a potential alternative biocontrol method to inhibit the pathogen $[13,14]$. Virulent phages cause bacterial host cell lysis and not only function to control bacterial populations but also can be used as indicators of bacterial contamination in fecal samples $[15,16]$ and as a potential tool for identifying specific bacterial strains $[17,18]$. A multivalent virulent bacteriophage would be a good selection for phage therapy because of its wide host range.

Phages have already been tested against salmonellae and other pathogens in humans and animals, with advantages compared to antibiotics [19-22]. Nevertheless, due to their high specificity, they can preferably produce in their natural hosts $[23,24]$, as the pathogenic hosts might release cell debris, endotoxins and exotoxins which would interfere when found in the crude phage lysate [21,25-27]. The issue can be slightly overcome by use of nonpathogenic host thus eliminating the interference risk of a pathogen $[23,26,28]$. Consequently, it would also simplify the purification, leading to reduced cost and increased safety of phage preparations. However, this seems to be a difficult approach due to the rare presence of multivalent phages $[21,23,28,29]$

The aim of this study was to isolate, enrich and purify bacteriophages from poultry fecal matter and further determination its molecular weight and polyvalence. Finally, detection of specific genes and mutation in them, if any, by whole genome sequencing of the bacteriophage DNA.

\section{Materials and Methods}

\section{Isolation, enrichment and purification of bacteriophages}

Host bacterial cultures: Salmonella strains and Escherichia Coli strain used as phage hosts were obtained from the Microbial Type Culture Collection (Table 1). Freeze-dried primary cultures were reconstituted in Luria-Bertanibroth overnight at $37^{\circ} \mathrm{C}$. Secondary culture was prepared by inoculating on nutrient agar slants cultures, grown overnight at $37^{\circ} \mathrm{C}$, sealed and stored in dark at $5^{\circ} \mathrm{C}$. Subcultures were produced weekly or biweekly as needed.Nutrient agar plates were

*Corresponding author: Ramesh K. Kothari, Department of Microbiology, Christ College, Rajkot, Gujarat, India, Tel: 9428288511; E-mail: kothari1971@gmail.com

Received February 17, 2014; Accepted March 28, 2014; Published March 31 2014

Citation: Bhensdadia DV, Bhimani HD, Nathani NM, Rawal CM, Koringa PG, et al. (2014) Isolation, Molecular Characterization and Insight into the Genome Sequence of $E$. Coli Bacteriophage ADB-2 from Poultry Fecal Sample. Next Generat Sequenc \& Applic 1: 101. doi:10.4172/2469-9853.1000101

Copyright: @ 2014 Bhensdadia DV, et al. This is an open-access article distributed under the terms of the Creative Commons Attribution License, which permits unrestricted use, distribution, and reproduction in any medium, provided the original author and source are credited. 
Citation: Bhensdadia DV, Bhimani HD, Nathani NM, Rawal CM, Koringa PG, et al. (2014) Isolation, Molecular Characterization and Insight into the Genome Sequence of E. Coli Bacteriophage ADB-2 from Poultry Fecal Sample. Next Generat Sequenc \& Applic 1: 101. doi:10.4172/24699853.1000101

Page 2 of 7

\begin{tabular}{|c|c|c|}
\hline Serial No. & Host Name & MTCC No. \\
\hline 1. & Salmonella typhimurium & 98 \\
\hline 2. & Salmonella enteritidis & 3219 \\
\hline 3. & Salmonella typhi & 733 \\
\hline 4. & E.coli & 1610 \\
\hline 5. & E.coli & 739 \\
\hline 6. & E.coli & 476 \\
\hline 7. & Entero bacteraerogens & 2822 \\
\hline 8. & Protease vulgeris & 742 \\
\hline 9. & Pseudomonas aerugenosa & 741 \\
\hline 10. & Salmonella paratyphi A & 735 \\
\hline 11. & Shigellaflexneri & 1457 \\
\hline 12. & S. aureus & 96 \\
\hline
\end{tabular}

Table 1: List of Bacterial strain collected from MTCC.

checked for purity and uniformity and working cultures prepared by transfer of single isolated colonies to LB broth.

Collection of poultry excreta: 32 Samples of 30-50 g poultry excreta were collected from nine different poultry farms in Gujarat, India, in sterile sample collector (Hi-media) in December 2008; February 2009; May 2009 and June 2009. Samples were collected in various forms such as freshly laid fecal sample, dry fecal sample and semi-solid fecal samples under guidance of veterinary doctor and curator of poultry farm.

Isolation of bacteriophage: A suspension of fecal contents $\left(1: 9\right.$, w/v) was prepared in SM buffer and incubated at $40^{\circ} \mathrm{C}$ for $24 \mathrm{hrs}$ with gentle agitation followed by centrifugation at $13,000 \times \mathrm{g}$ for 10 minutes to remove bulk debris. The supernatant was then filtered through a $0.22 \mu \mathrm{m}$-pore size membrane filter to remove any remaining bacterial cells. This filtered supernatant was added to equal quantity of double strength T-broth (g/L): Peptone,10g; Meat extract, $3 \mathrm{~g} ; \mathrm{NaCl}$, $5 \mathrm{~g}$; Glucose, $1 \mathrm{~g} ; \mathrm{CaCl}_{2}, 0.2 \mathrm{~g} ; \mathrm{MgSO}_{4}, 0.5 \mathrm{~g} ; \mathrm{pH} 7.4$ (with $\mathrm{HCl}$ or $\mathrm{NaOH}$ ) and incubated at $37^{\circ} \mathrm{C}$ for $24 \mathrm{hrs}$ with shaking. Resultant growth culture was treated with chloroform to release phage encoded in it. Then centrifuged at $13,000 \times \mathrm{g}$ for $5 \mathrm{~min}$ and supernatant was passed through $0.22 \mu \mathrm{m}$ filter, this filtrate was used in Double Agar Layer (DAL) plaque assay against the host bacterium. For plaque assay, enrichment of phage lysate was performed by adding to equal quantity of T-broth inoculated with $1 \mathrm{ml}$ of overnight grown culture of bacterial host and incubated at $37^{\circ} \mathrm{C}$ for $24 \mathrm{hrs}$ under agitation. Chloroform was added and the suspension was centrifuged at $10,000 \times \mathrm{g}$ for $15 \mathrm{~min}$, supernatant was collected and filtered through $0.45 \mu \mathrm{m}$ membrane filter. This filtrate was used to prepare serial dilutions of phage lysate with sterile saline dilution. $0.5 \mathrm{ml}$ of young culture of host and $0.5 \mathrm{ml}$ of each dilution were transferred to $10 \mathrm{ml}$ of melted top agar tubes. Test suspensions were mixed thoroughly by vortexing and dispensed uniformly over the surface of $20 \mathrm{ml}$ of hard nutrient agar in $96 \mathrm{~mm}$ diameter plate for each dilution. Melted agar overlays were allowed to harden at room temperature then plates were inverted and incubated overnight at $37^{\circ} \mathrm{C}$. Plaque were counted or individually sub-cultured as appropriate to the enumeration or isolation protocol.

Enrichment of isolated bacteriophage: Fecal samples were reconstituted in SM buffer and treated with chloroform and stored at $40^{\circ} \mathrm{C}$ overnight to allow larger suspended sediments to settle out. These crudely clarified samples were then passed through $0.22 \mathrm{~mm}$ syringe filters. Lytic phages were selectively enriched by mixing filtered effluent with double strength trypticase soy broth inoculated with an actively growing culture of host. (E. coli MTCC 739, S. typhimurium
MTCC 98 and S. typhi MTCC 733). After overnight incubation at $35^{\circ} \mathrm{C}$, chloroform was added and samples were stored at $50^{\circ} \mathrm{C}$. Enriched samples were tested by Double Agar Layer (DAL) plaque assay against individual respective host. For isolation of phages, enriched samples were diluted in sterile saline in 10-fold series and used in DAL plaque tests at appropriate dilutions to yield separated individual plaques suitable for single- plaque transfer. All phage titers reported in this thesis are mean values of at least 2 measurements. Phage isolates (E. coli, S. typhimurium and S. typhi phage) were tested against 13 different strains of taxonomically related bacteria. Phage lysate were allowed to enrich into T-broth inoculated with respective bacterial test hosts and incubated overnight at $37^{\circ} \mathrm{C}$. Plaque formation, indicating a susceptible host for the respective phage, was assessed after $24 \mathrm{hrs}$. Polyvalence of isolated Bacteriophage was also tested by Spot assay method.

\section{Isolation of $E$. coli and S. typhi as a natural host of phages}

Fecal samples were collected from chicken in different district of Gujarat state. 9 Poultry fecal sample from which bacteriophage were isolated used for the isolation of their host bacteria. Suspension of fecal contents $(1: 9, \mathrm{w} / \mathrm{v})$ was prepared in SM buffer (50 mM Tris$\mathrm{HCl}$ [pH 7.5], $0.1 \mathrm{M} \mathrm{NaCl}, 8 \mathrm{mM} \mathrm{MgSO} 4.7 \mathrm{H} 2 \mathrm{O}$, and $0.01 \%$ gelatin) and incubated at $40^{\circ} \mathrm{C}$ for $24 \mathrm{hrs}$ with gentle agitation to allow bacteria to elute into the buffer. This suspension was then subjected to centrifugation at $5,000 \times \mathrm{g}$ for $10 \mathrm{~min}$ to remove bulk debris. For the isolation of E. coli and S. typhi Brilliant Green Agar (BGA) and Mac Conkey's Lactose Agar (MLA) selective medium were used. Agglutinability of the suspected Salmonella culture with Salmonella polyvalent 'O' sera (SPAN Diagnostic Ltd, INDIA) was tested using agglutination test. Eosine Methylene Blue and Mac Conkey's agar were used for the preliminary identification of suspected E. coli isolates. Further identification was carried out on the basis of morphology, cultural characteristics, biochemical reaction. Growth curve pattern for all the 37 bacterial isolates were carried out by inoculating loop full culture in to Nutrient broth medium. Cultures were grown overnight in $\mathrm{CMB}$ medium and next day transferred to $\mathrm{CM}$ agar plates and slants. They were incubated at $37^{\circ} \mathrm{C}$ for $24 \mathrm{~h}$. In order to study diversity and identification of the organisms, the isolates were inoculated into different biochemical media supplemented with $\mathrm{NaCl}(5 \%, \mathrm{w} / \mathrm{v})$ and incubated at $37^{\circ} \mathrm{C}$ for $24-72 \mathrm{~h}$ and results were subsequently observed. The biochemical tests performed includes catalase and oxidase test, urea hydrolysis, indole production, $\mathrm{H}_{2} \mathrm{~S}$ production, ammonia production, nitrate reduction, triple sugar iron reaction and sugar fermentation test following standard protocol [30].

\section{Determination of antibiogram of isolated natural host bacteria by disc diffusion technique}

The sensitivity of organism against 32 antimicrobial agents was determined by the disc diffusion technique. $0.1 \mathrm{ml}$ overnight grown culture of isolated bacteria $\left(1 \times 10^{7} \mathrm{cfu} / \mathrm{ml}\right)$ mixed with $15 \mathrm{ml}$ melted $\mathrm{N}$-Agar at $45-50^{\circ} \mathrm{C}$ and poured on base agar containing petriplate. After that antibiotic discs were applied with sterile forceps to ensure even contact with the medium. All plates were incubated at $37^{\circ} \mathrm{C}$ for 24 hrs.

\section{S rRNA gene sequencing and phylogenetic classification}

The PCR primers used to amplify $16 \mathrm{~S}$ rDNA fragments were the bacteria - specific primers (Lane, 1991) F27 (5'-AGA GTT TGA TCM TGG CTC AG-3'); and R1492 (5'-ATA GGY TAC CTT GTT ACG ACT-3'). PCR amplification $25 \mu \mathrm{l}$ reaction mixture was performed by 
Citation: Bhensdadia DV, Bhimani HD, Nathani NM, Rawal CM, Koringa PG, et al. (2014) Isolation, Molecular Characterization and Insight into the Genome Sequence of E. Coli Bacteriophage ADB-2 from Poultry Fecal Sample. Next Generat Sequenc \& Applic 1: 101. doi:10.4172/24699853.1000101

Page 3 of 7

Thermal Cycler (ABI, USA) using the following program: Denaturing at $95^{\circ} \mathrm{C}$ for $5^{\prime}$, followed by 30 cycles of 30 s of denaturing at $95^{\circ} \mathrm{C}, 30 \mathrm{~s}$ of annealing at $50^{\circ} \mathrm{C}$ and $2^{\prime}$ of elongation at $72^{\circ} \mathrm{C}$ with a final extension at $72^{\circ} \mathrm{C}$ for $10^{\prime}$. The PCR product ( $1400 \mathrm{bp}$ ) was cleaned by using a Qiagen DNA Gel Extraction Kits (QIAGEN, CA). Sequencing was performed for all isolates (purified PCR product) using above primer with an ABI Prism 310 Genetic analyser (Applied Biosystems Inc., CA) using Big Dye Terminator (version 3.1) at Animal Biotechnology laboratory, AAU, Anand, Gujarat, India. The 16s rDNA sequence for Isolates were initially analyzed at NCBI server (http://www.ncbi. nlm.nih.org) using BLAST tool and corresponding sequences were downloaded. Evolutionary history was inferred using the Neighborjoining method [31]. The tree was drawn to scale, with branch lengths in the same units as those of the evolutionary distance used to infer the phylogenetic tree [32].

\section{Whole genome sequencing of Escherichia phage adb-2 and} functional annotation

Genomic DNA was extracted from the stock by the alkaline lysis method. The whole-genome sequencing of Escherichia phage ADB-2 was performed using Ion Torrent PGM (Ion 200-bp sequencing kit) (Life Technologies). The generated reads were De Novo assembly using Newbler version 2.6, followed by genome annotation and comparative analysis of the genome were done using Rapid Annotation using Subsystem Technology (RAST) [33].

\section{Results and Discussion}

Out of 32 samples tested for the presence of phages of E. coil and S. typhimurium and $S$. typhi by double agar layer plaque method, 5 samples showed the presence of E. coli phages named as ADB-1, ADB -2 , ADB -3, MH -2 and MH-5 isolated from the sample AM-2, AM-4, AM-5 , MH-2 and MH- 4 respectively. 4 samples showed the presence of S. typhimurium phage named as SM-3, SM-5, LHSM- 4 and LHSM - 5 isolated from sample DK-3, DK-5, LH-4 and LH-5 respectively (Table 2).

Standard DAL method used for the determination of Phage titers, performed in triplicates showed that Dh-T1 sample had the highest pfu while ST-4 was found to be having the lowest pfu value (Table 3). The data of pfu is very useful for the further experiment and also very useful for the determination of infectivity of phage to their respective host bacteria.
13 bacterial strains were tested for sensitivity against the isolated phages by e Spot Test and DAL method. Ec-2, ADB-2, Ec-5 and ST-4 isolates of phage were found host specific while SM-3 and SM-5 were found polyvalent bacteriophage, SM-3 was having the capacity to

\begin{tabular}{|c|c|c|c|c|}
\hline Name of Poultry farm & $\begin{array}{l}\text { Sample } \\
\text { code }\end{array}$ & $\begin{array}{l}\text { E. coli } \\
\text { phage }\end{array}$ & $\begin{array}{c}\text { S. typhimurium } \\
\text { phage }\end{array}$ & S. typhi phage \\
\hline \multirow{3}{*}{ Dhebakuva - 1} & DK-1 & - & - & - \\
\hline & DK-2 & - & - & - \\
\hline & Dk-3 & - & + & - \\
\hline \multirow{2}{*}{ Dhebakuva -2 } & DK-4 & - & - & - \\
\hline & Dk-5 & - & + & - \\
\hline \multirow{2}{*}{ Dharmaj } & DJ-1 & - & - & ND \\
\hline & $\mathrm{Dj}-2$ & - & - & ND \\
\hline \multirow{3}{*}{ Ankalav } & Ak-1 & - & - & ND \\
\hline & AK-2 & - & - & ND \\
\hline & AK-3 & - & - & ND \\
\hline \multirow{4}{*}{$\begin{array}{c}\text { Anand Agriculture } \\
\text { University }\end{array}$} & LH-1 & - & - & - \\
\hline & LH-4 & - & + & - \\
\hline & LH-5 & - & + & - \\
\hline & $\mathrm{CH}-2$ & - & - & - \\
\hline \multirow{4}{*}{ Rajkot } & RJ-1 & - & - & ND \\
\hline & RJ-2 & - & - & ND \\
\hline & RJ-3 & - & - & ND \\
\hline & RJ-4 & - & - & ND \\
\hline \multirow{6}{*}{$\begin{array}{l}\text { Mustafa Poultry farm } \\
\text { AMRELI }\end{array}$} & AM-1 & - & - & - \\
\hline & AM-2 & + & - & - \\
\hline & AM-3 & - & - & - \\
\hline & AM-4 & + & - & + \\
\hline & AM-5 & + & - & + \\
\hline & AM-6 & - & - & - \\
\hline \multirow{4}{*}{ Mahuva Poultry farm - 1} & $\mathrm{MH}-1$ & - & - & - \\
\hline & $\mathrm{MH}-2$ & + & - & - \\
\hline & $\mathrm{MH}-3$ & - & - & - \\
\hline & $\mathrm{MH}-4$ & + & - & - \\
\hline \multirow{4}{*}{ Mahuva Poultry farm - 2} & $\mathrm{MH}-5$ & - & - & ND \\
\hline & $\mathrm{MH}-6$ & - & - & ND \\
\hline & $\mathrm{MH}-7$ & - & - & ND \\
\hline & $\mathrm{MH}-8$ & - & - & ND \\
\hline
\end{tabular}

Table 2: Isolation of Coliphage from poultry fecal samples.

\begin{tabular}{|c|c|c|c|c|c|c|}
\hline \multirow[t]{2}{*}{ Dilution } & \multicolumn{3}{|c|}{ No. of plaque $(\mathrm{Y})$} & \multirow[t]{2}{*}{$\mathrm{N}=\mathrm{Y} / \mathrm{VX}(\mathrm{pfu} / \mathrm{ml})$} & \multirow[t]{2}{*}{ Mean (pfu/ml) } & \multirow[t]{2}{*}{ Mean (pfu/ml) } \\
\hline & Plate -1 & Plate -2 & Plate -3 & & & \\
\hline $10^{-1}$ & Uncountable & Uncountable & Uncountable & - & - & - \\
\hline $10^{-2}$ & Uncountable & Uncountable & Uncountable & - & - & - \\
\hline $10^{-3}$ & Uncountable & Uncountable & Uncountable & - & - & - \\
\hline $10^{-4}$ & Uncountable & Uncountable & Uncountable & - & - & - \\
\hline $10^{-5}$ & Uncountable & Uncountable & Uncountable & - & - & - \\
\hline $10^{-6}$ & Uncountable & Uncountable & Uncountable & - & - & - \\
\hline $10^{-7}$ & Uncountable & Uncountable & Uncountable & & & \\
\hline $10^{-8}$ & Uncountable & 293 & 421 & $714 \times 10^{8}$ & $7.14 \times 10^{10}$ & \multirow{4}{*}{$8.5 \times 10^{11}$} \\
\hline $10^{-9}$ & 467 & 351 & 259 & $718 \times 10^{9}$ & $72 \times 10^{10}$ & \\
\hline $10^{-10}$ & 33 & 102 & 48 & $121 \times 10^{10}$ & $121 \times 10^{10}$ & \\
\hline $10^{-11}$ & 0 & 16 & 6 & $14 \times 10^{11}$ & $140 \times 10^{10}$ & \\
\hline $10^{-12}$ & 0 & 0 & 0 & - & & \\
\hline $10^{-13}$ & 0 & 0 & 0 & - & & \\
\hline $10^{-14}$ & 0 & 0 & 0 & - & & \\
\hline
\end{tabular}


Citation: Bhensdadia DV, Bhimani HD, Nathani NM, Rawal CM, Koringa PG, et al. (2014) Isolation, Molecular Characterization and Insight into the Genome Sequence of E. Coli Bacteriophage ADB-2 from Poultry Fecal Sample. Next Generat Sequenc \& Applic 1: 101. doi:10.4172/24699853.1000101

Page 4 of 7

infect E. coli, S. typhimurium and S. enteritidis, while SM-5 infected S. typhimurium and S. enteritidis (Table 4). Due to the ability to infect various species of bacteria, it has been concluded that the isolated bacteriophages SM-3 and SM-5 can become an effective agent in the effort to reduce the incidence of salmonellosis in poultry. Further study of SM-3 and SM-5 will also provide the basis for future experiments for the phages as a potential indicator and biocontrol agent in poultry $[34,35]$.

For the treatment of various infectious diseases antibiotics have remained as the "magic bullet" since very long period of time. Available antibiotics have successfully been used for the treatment of countless number of infections in humans and animals. But eventually many antibiotics have lost their effectiveness [36]. Bacteria naturally developed various resistant mechanisms against the available antibiotics and this process still continuous to develop more and more resistance.

The isolates when tested against different antibiotics showed that the E. coli host for ADB-2 phage was sensitive against Tetracyline, Lomefloxacine, Sparfloxacine, Amoxyciline, Ofloxacine (Zone diameter $\geq 2.0 \mathrm{~cm}$ ), showed intermediate resistance against Oxytetracyline, Penicillin, Oxacillin, Cephalothin, Amkalin (Zone of diameter $\leq$ $0.5 \mathrm{~cm}$ ) and highly resistance against Bacitracin, Cephaloridine, Cephadroxil, Ceftazidime, Ampicilline, Lincomycin, Co-trimoxazole. S. typhiARJ-2 phage was observed to be sensitive against Lomefloxacine, Sparfloxacine, Amoxyciline, Ofloxacine, Ceftriaxone (Zone diameter $\geq 2.0$ ); it showed intermediate resistance against Bacitracin, Polymyxin, Ampicillin, Erythtromycin, Clindamycin, Penicillin, Oxacillin, (Zone of diameter $\leq 0.5 \mathrm{~cm}$ ) and higher resistance against Cephaloridine, Cephadroxil, Ceftazidime, Lincomycin, Co-trimoxazole, Oxytetracylin (Table 5). Studies have reported that the major cause of antibiotic resistance is the poultry feed as supplements and uncontrolled antibiotic usage [37]. Determination of antibiogram and drug resistance pattern of the isolates will provide the clinician an idea regarding therapeutic schedule needed in individual cases. The data of antibiogram is also a useful tool to devise a comprehensive chemoprophylactic and chemotherapeutic drug schedule and doses of antibiotic within a geographical area.

\begin{tabular}{|c|c|c|c|c|c|c|}
\hline \multirow[t]{2}{*}{ Host } & \multicolumn{4}{|c|}{ E. coli phage } & \multirow{2}{*}{\begin{tabular}{|c|}
$\begin{array}{c}\text { S. typhimurium } \\
\text { phage }\end{array}$ \\
SM-5
\end{tabular}} & \multirow{2}{*}{$\begin{array}{c}\begin{array}{c}\text { S. typhi } \\
\text { phage }\end{array} \\
\text { ST-4 }\end{array}$} \\
\hline & EC-2 & ADB-2 & EC-5 & SM-3 & & \\
\hline E. coli 1610 & $+/-\mathrm{c}$ & $-1+\mathrm{t}$ & $+/-\mathrm{c}$ & $-1+t$ & - & ND \\
\hline E. coli 739 & $+\mathrm{tc}$ & $+c$ & $+\mathrm{tc}$ & ND & ND & - \\
\hline E. coli 476 & $+c$ & $+c$ & $+\mathrm{tc}$ & - & - & ND \\
\hline E. coli ADB-2 & - & $+\mathrm{tc}$ & ND & ND & ND & ND \\
\hline E. aerogens & - & - & - & - & - & - \\
\hline S. typhimurium & - & - & - & $+/-\mathrm{c}$ & $+/-\mathrm{c}$ & - \\
\hline S. enteritidis & - & - & - & $+/-\mathrm{t}$ & $+/-\mathrm{t}$ & ND \\
\hline S. typhi & - & - & - & - & - & $+\mathrm{tc}$ \\
\hline S. peratyphi A & - & - & - & - & - & ND \\
\hline Shigellaflexneri & - & - & - & - & - & ND \\
\hline P. vulgaris & - & - & - & - & - & ND \\
\hline P. aeruginosa & - & - & - & ND & ND & ND \\
\hline S. areus & - & - & - & - & - & ND \\
\hline
\end{tabular}

Note: + Sign indicates plaque formation; +/- indicates small or diffuse plaque; -/+ indicates a very small plaque; - indicates no plaque formation; $c$ indicates a clear plaque; $t$ indicates a turbid plaque; tc indicates a turbid plaque with a clear center; ND indicates "no description" due to apparent loss of infectivity in storage following isolation

Table 4: Host range of isolated bacteriophages.

\begin{tabular}{|c|c|c|c|}
\hline Serial No. & Antibiotics & $\begin{array}{l}\text { Concentration } \\
\text { (micrograms) }\end{array}$ & $\begin{array}{c}\text { E. coli } \\
\text { (Inhibition zone } \\
\text { diameter in cm.)* }\end{array}$ \\
\hline 1 & Tetracycline & - & 2.00 \\
\hline 2 & Bacitracin & - & $\mathrm{R}$ \\
\hline 3 & Cephaloridine & - & $\mathrm{R}$ \\
\hline 5 & Polymyxin & 300 & 0.9 \\
\hline 6 & Neomycin & 30 & 1.4 \\
\hline 7 & Novobiocin & 30 & 1.1 \\
\hline 8 & Kanamycin & 30 & 1.3 \\
\hline 9 & Amikacin & 30 & 1.6 \\
\hline 10 & Lomefloxacin & 10 & 2.5 \\
\hline 11 & Cephadroxil & 30 & $\mathrm{R}$ \\
\hline 12 & Sparfloxacin & 5 & 2.3 \\
\hline 13 & Netillin & 30 & 1.4 \\
\hline 14 & Ceftazidime & 30 & $\mathrm{R}$ \\
\hline 19 & Cefaperazone & 75 & 1.2 \\
\hline 20 & Ampicillin & 10 & $\mathrm{R}$ \\
\hline 21 & Cephotaxime & 30 & 1.4 \\
\hline 22 & Augmentin & 30 & 1.3 \\
\hline 23 & Cefuroxime & 30 & 1.2 \\
\hline 24 & Ceftriaxone & 30 & 1.9 \\
\hline 25 & Amoxycillin & 10 & 2.2 \\
\hline 26 & Erythromycin & 15 & 0.7 \\
\hline 27 & Clindamycin & 02 & 1.1 \\
\hline 28 & Gentamycin & 10 & 1.4 \\
\hline 29 & Ofloxacin & 05 & 2.4 \\
\hline 30 & Lincomycin & 02 & $\mathrm{R}$ \\
\hline 31 & Ciprofloxacin & 05 & 1.6 \\
\hline 32 & Tobramycin & 10 & 1.3 \\
\hline 33 & Cotrimoxazole & 25 & $\mathrm{R}$ \\
\hline 34 & Norfloxacin & 10 & 1.4 \\
\hline 35 & Oxytertracyline & 30 & 0.3 \\
\hline 36 & Amoxyclav & 30 & 0.6 \\
\hline 37 & Penicillin & 10 (Units) & 0.5 \\
\hline 38 & Oxacillin & 1 & 0.3 \\
\hline 39 & Cephalothin & 30 & 0.4 \\
\hline 40 & Amkalin & 30 & 0.4 \\
\hline
\end{tabular}

${ }^{*} \mathrm{R}$ instead of numerical value in the diameter column stands for 'Resistant' Table 5: Antibiogram Of isolated E. coli ADB-2 host bacteria.

Nine samples out of 32 samples from which the phages had been isolated were used for theisolation of host bacteria. Total six E.coli isolates and four salmonella host bacteria were isolated based on their colony characteristics and cell morphology (Table 6). Organisms grown on selective and differential medium, showed characteristic pigmentation of colonies like white, dirty white, metallic green sheen, black cantered and light yellow. The isolate ADB-2 produced green metallic sheen colony on EMB Agar and SMARJ-2 produced dark black colony on WB Agar. Size of colonies varied from small to moderate to large having smooth or rough texture with even, uneven, margins and circular, rhizoid and irregular forms. Microscopic observations revealed that all bacterial isolates were Gram negative organisms.

Biochemical characterization is the primary tool for identification of microorganisms [30]. Tables 7 and 8 show the biochemical test and sugar fermentation capacity of the suspected E. coli isolate. All the isolates except $\mathrm{MH}-3$ and $\mathrm{LH}-6$ were found to be positive for the catalase production. IMViC the key test for the identification of coli-form groups of organisms was also performed to confirm. All 
Citation: Bhensdadia DV, Bhimani HD, Nathani NM, Rawal CM, Koringa PG, et al. (2014) Isolation, Molecular Characterization and Insight into the Genome Sequence of E. Coli Bacteriophage ADB-2 from Poultry Fecal Sample. Next Generat Sequenc \& Applic 1: 101. doi:10.4172/24699853.1000101

Page 5 of 7

the isolates gave deamination and nitrate reduction test positive except DK-5. All the isolates showed negative for Gelatin hydrolysis. Isolate ADB-1, MH-3 and DK-5 hydrolyzed starch. All the isolates ferment glucose and fructose, maltose and sucrose. Lactose and xylose fermented by ADB-2 and DK-5 only. All the isolates showed $35^{\circ} \mathrm{C}$ as optimum temperature for their growth and grew at salt concentration up to $1 \%$.

\begin{tabular}{|c|c|c|c|}
\hline Poultry farm & Sample & E. coli & Salmonella \\
\hline \multirow{3}{*}{ Mustafa Poultry farm AMRELI } & $\mathrm{AM}-2$ & $\mathrm{ADB}-1$ & SMARJ - 1 \\
\cline { 2 - 4 } & $\mathrm{AM}-4$ & $\mathrm{ADB}-2$ & SMARJ - 2 \\
\cline { 2 - 4 } & $\mathrm{AM}-5$ & - & - \\
\hline \multirow{2}{*}{ Mahuva Poultry farm } & $\mathrm{MH}-2$ & $\mathrm{MH}-3$ & - \\
\cline { 2 - 4 } & $\mathrm{MH}-4$ & $\mathrm{MH}-4$ & - \\
\hline Dhebakuva - 1 & $\mathrm{DK}-3$ & - & $\mathrm{SMDK}-3$ \\
\hline Dhebakuva - 2 & $\mathrm{DK}-5$ & $\mathrm{DK}-5$ & - \\
\hline \multirow{2}{*}{ Anand Agricultural University } & $\mathrm{LH}-4$ & $\mathrm{LH}-6$ & $\mathrm{SMLH}-4$ \\
\cline { 2 - 5 } & $\mathrm{LH}-5$ & - & - \\
\hline
\end{tabular}

Table 6: Isolation of Coliphage from poultry fecal samples.

\begin{tabular}{|c|c|c|c|c|c|c|c|}
\hline \multicolumn{2}{|c|}{ Biochemical Test } & ADB-1 & ADB-2 & MH-3 & $\mathrm{MH}-4$ & DK-5 & LH-6 \\
\hline \multicolumn{2}{|c|}{ Catalase } & + & + & - & + & + & - \\
\hline \multicolumn{2}{|c|}{ Indole production } & + & + & + & + & - & + \\
\hline \multicolumn{2}{|c|}{ Methyl Red } & + & + & + & + & + & + \\
\hline \multicolumn{2}{|c|}{ Vogues Proskauer } & - & - & - & - & + & - \\
\hline \multicolumn{2}{|c|}{ Citrate Utilization } & - & - & + & - & - & + \\
\hline \multicolumn{2}{|c|}{ Deamination } & + & + & + & + & - & + \\
\hline \multicolumn{2}{|c|}{ Nitrate Reduction } & + & + & + & + & + & + \\
\hline \multicolumn{2}{|c|}{ Urea } & + & - & - & - & + & - \\
\hline \multirow{3}{*}{$\begin{array}{l}\frac{n}{n} \\
\frac{2}{2} \\
\frac{0}{0} \\
⿱ 亠 乂 \\
x\end{array}$} & Starch & + & - & + & - & + & - \\
\hline & Casein & - & - & + & - & - & - \\
\hline & Gelatin & - & - & - & - & - & - \\
\hline \multirow{4}{*}{ 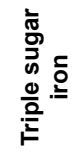 } & Slant & $A C$ & $A C$ & $A C$ & $A C$ & $A C$ & $A K$ \\
\hline & Butt & $A C$ & $A C$ & $A C$ & $A K$ & $A C$ & $A C$ \\
\hline & $\mathrm{H}_{2} \mathrm{~S}$ & - & - & - & - & - & - \\
\hline & Gas & + & + & - & - & + & + \\
\hline
\end{tabular}

Note: + Positive test; - , Negative test; $A C=$ Acidic reaction; $A K=$ Alkaline Reaction Table 7: Biochemical test of $E$. coli isolates.
Salmonella genus contains more than 2000 species. Among the 4 isolates from salmonella phage positive sample, all the isolates except SMDK-3 showed catalase and methyl red positive. SMARJ-2 and SMLH-4 also utilized citrate. All the isolates except SMARJ-2 gave deamination test positive. In Sugar fermentation test all 4 isolates ferment glucose and fructose. In case of xylose, only SMARJ-2 and SMDK-3 were found to be positively utilizing. $35^{\circ} \mathrm{C}$ is the optimum temperature for all except SMARJ-2 that showed growth at $25^{\circ} \mathrm{C}$ to $55^{\circ} \mathrm{C}$ temperature range. Selected isolate ADB-2 and SMARJ-2 was identified on the basis of $16 \mathrm{~S}$ rDNA gene homology. The use of $16 \mathrm{~S}$ rRNA gene sequences to study bacterial phylogeny and taxonomy has been used due to several reasons like its presence in almost all bacteria, the conserved function of the $16 \mathrm{~S}$ rRNA gene and the size of the 16S rRNA gene is large enough for analysis and interpretation
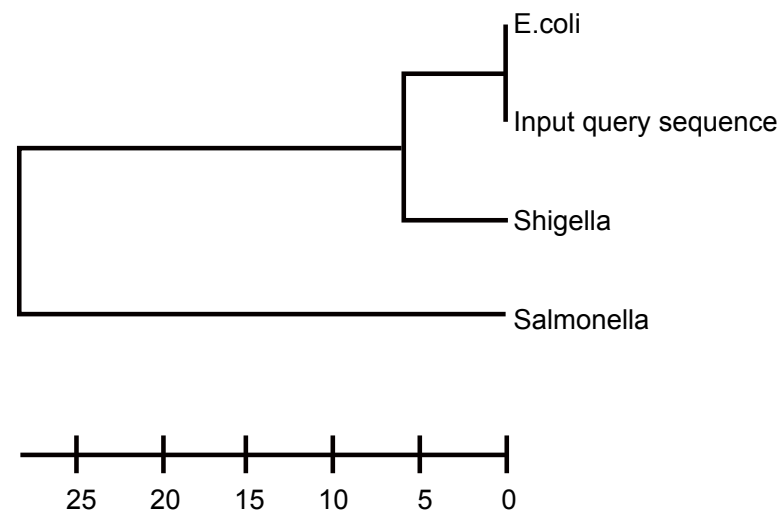

Figure 1: The evolutionary history was inferred using the Neighbor-Joining method. The optimal tree with the sum of branch length $=62.11780002$ is shown. The phylogenetic tree was linearized assuming equal evolutionary rates in all lineages The tree is drawn to scale, with branch lengths in the same units as those of the evolutionary distances used to infer the phylogenetic tree. The evolutionary distances were computed using the Maximum Composite Likelihood method and are in the units of the number of base substitutions per site. Codon positions included were $1^{\text {st }}+2^{\text {nd }}+3^{\text {rd }}+$ Noncoding. All positions containing gaps and missing data were eliminated from the dataset. There were a total of 431 positions in the final dataset. Phylogenetic analyses were conducted in MEGA4.

Model: Nucleotide: Maximum Composite Likelihood

$[1]$ = Shigella; $[2]$ = Input query sequence; $[3]$ = E. coli; [4] = Salmonella

\begin{tabular}{|c|c|c|c|c|c|c|c|c|c|c|c|}
\hline \multirow{2}{*}{\multicolumn{2}{|c|}{ Biochemical Test }} & \multicolumn{2}{|c|}{ ADB-1 } & \multicolumn{2}{|c|}{ ADB-2 } & \multicolumn{2}{|c|}{ MH-3 } & \multicolumn{2}{|c|}{ MH-4 } & \multicolumn{2}{|c|}{ DK-5 } \\
\hline & & Acid & Gas & Acid & Gas & Acid & Gas & Acid & Gas & Acid & Gas \\
\hline \multirow{6}{*}{ 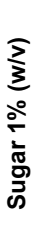 } & Glucose & + & + & + & + & + & + & + & + & + & + \\
\hline & Fructose & + & + & + & + & + & + & + & + & + & - \\
\hline & Maltose & + & - & + & + & + & + & + & + & - & + \\
\hline & Sucrose & + & + & + & + & + & - & + & - & + & + \\
\hline & Lactose & + & - & + & + & - & - & - & - & + & + \\
\hline & Xylose & - & - & + & + & - & - & + & - & + & + \\
\hline \multirow{3}{*}{$\frac{\dot{\varrho}}{\stackrel{\Xi}{\varrho}}$} & $25^{\circ} \mathrm{C}$ & \multicolumn{2}{|c|}{ - } & \multicolumn{2}{|c|}{+} & - & & + & & - & \\
\hline & $35 \mathrm{C}$ & \multicolumn{2}{|c|}{+} & \multicolumn{2}{|c|}{+} & \multicolumn{2}{|c|}{+} & \multicolumn{2}{|c|}{+} & \multicolumn{2}{|c|}{+} \\
\hline & $55^{\circ} \mathrm{C}$ & \multicolumn{2}{|c|}{-} & \multicolumn{2}{|c|}{-} & \multicolumn{2}{|c|}{-} & \multicolumn{2}{|c|}{-} & \multicolumn{2}{|c|}{-} \\
\hline \multirow{4}{*}{$\begin{array}{l}\stackrel{0}{0} \\
\text { ठ̊ } \\
\frac{ \pm}{\pi} \\
\text { 心் }\end{array}$} & $0.5 \%$ & \multicolumn{2}{|c|}{+} & \multicolumn{2}{|c|}{+} & \multicolumn{2}{|c|}{+} & \multicolumn{2}{|c|}{+} & \multicolumn{2}{|c|}{+} \\
\hline & $1.0 \%$ & \multicolumn{2}{|c|}{+} & \multicolumn{2}{|c|}{+} & \multicolumn{2}{|c|}{+} & \multicolumn{2}{|c|}{+} & \multicolumn{2}{|c|}{+} \\
\hline & $2.0 \%$ & \multicolumn{2}{|c|}{-} & \multicolumn{2}{|c|}{-} & \multicolumn{2}{|c|}{+} & \multicolumn{2}{|c|}{+} & \multicolumn{2}{|c|}{+} \\
\hline & $5.0 \%$ & & & & & & & & & & \\
\hline
\end{tabular}

Table 8: Sugar fermentation and Biochemical test of $E$. coli isolates. 
Citation: Bhensdadia DV, Bhimani HD, Nathani NM, Rawal CM, Koringa PG, et al. (2014) Isolation, Molecular Characterization and Insight into the Genome Sequence of E. Coli Bacteriophage ADB-2 from Poultry Fecal Sample. Next Generat Sequenc \& Applic 1: 101. doi:10.4172/24699853.1000101

\section{Subsystem Information}

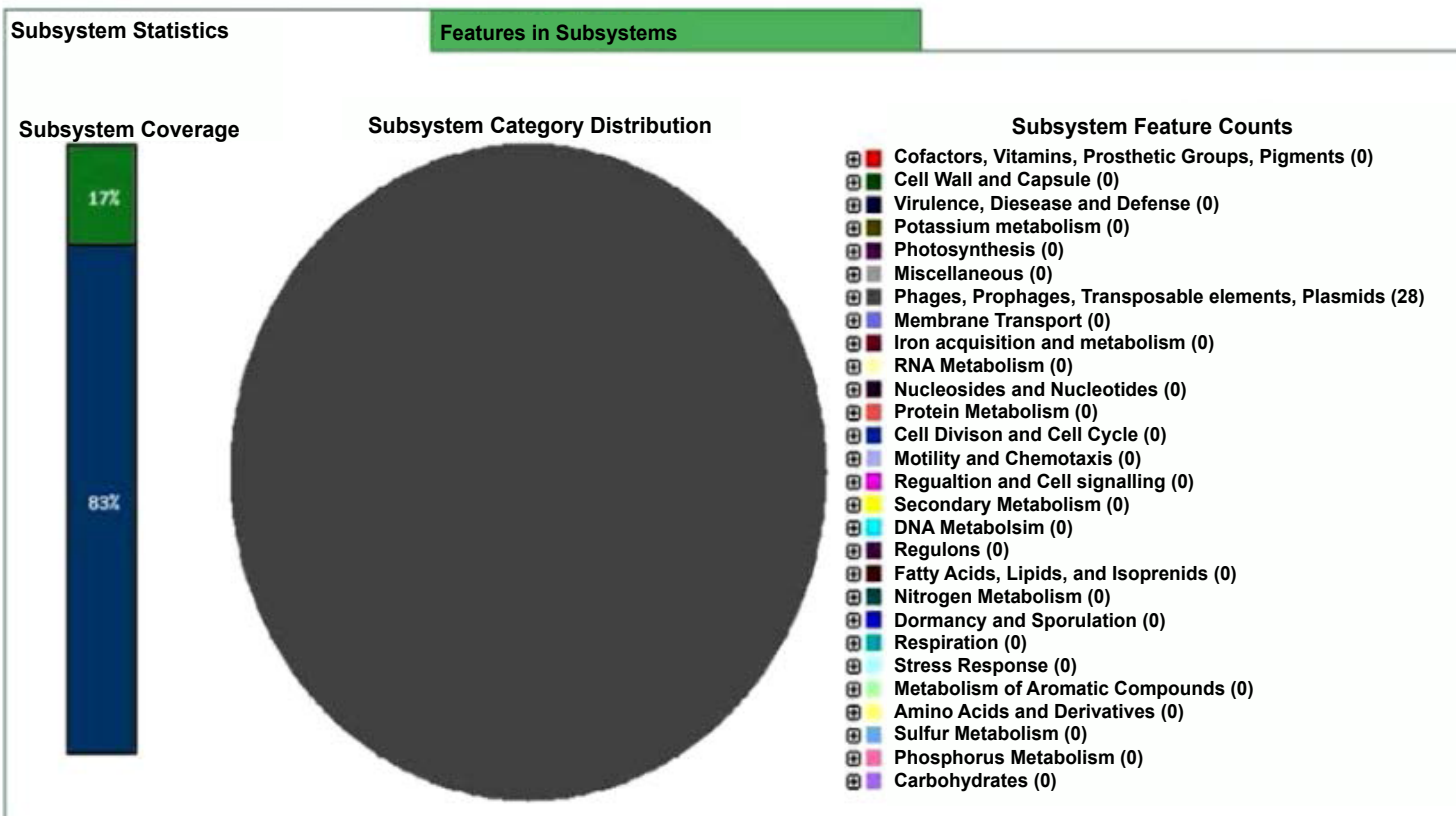

Figure 2: Sub system information of T1 Coliphage ADB-2.

[38]. As described in materials and methods, the $16 \mathrm{~S}$ rDNA gene was amplified by universal primers. These sequences were blast at NCBI and submitted to NCBI. The detailed reports on each of the isolate studied for $16 \mathrm{~S}$ rDNA shows aligned sequences of both culture studied for phylogenetic analysis. The sequence data were further analyzed for finding the closest homologs for the microbe by comparing gene sequence with reference strains. To analyze the phylogenetic position, the $16 \mathrm{~S}$ rDNA sequence of the strain ADB-2 (500 bp, JX094849), SMARJ-2 (542 bp, JX094848) were determined. Based on nucleotides homology and phylogenetic analysis the microbes were identified (Figure 1).

The data generated from the genomic library contained 229,781 reads and 45,496,800 nucleotide bases with average read length of 198 bases. The assembly using Newbler version 2.6 generated a 50,552 -bplong single chromosome.The phage has $46 \%$ GC with 76 predicted coding regions and 2 RNA genes. This genome contains functional genes related to phage structure andpackaging machinery like major capsid protein, unknown phage structure proteins, and terminase.

Phage neck protein, tail structure for host interaction like tail fiber protein, tail sheath protein, and tail-associated protein, phage DNA synthesis (helicase, DNA-directed RNA polymerases, endonuclease, and transcription regulator) and host lysis (endolysin without holing). These functional genes are scattered over the genome (Figure 2). The complete genome analysis of this phage provides new insight into its characteristics and interactions with Escherichia coli. Further comparative genomics would help us to understand the metabolic and adaptive complexity of such viruses.

\section{References}

1. Centers for Disease Control and Prevention (2005) Salmonella surveillance: annual summary, Atlanta, GA.

2. European Food Safety Authority (2004) The community summary report on trends and sources of zoonoses, zoonotic agents and antimicrobial resistance in the European Union in 2006. European Food Safety Authority, Parma, Italy.
3. Velge P, Cloeckaert A, Barrow P (2005) Emergence of Salmonella epidemics: the problems related to Salmonella enterica serotype Enteritidis and multiple antibiotic resistance in other major serotypes. Vet Res 36: 267-288.

4. Olsen RH, Frantzen C, Christensen H, Bisgaard M (2012) An investigation on first-week mortality in layers. Avian Dis 56: 51-57.

5. American Academy of Microbiology (2009) Antibiotic resistance: an ecological perspective on an old problem. Report of a colloquium, American Academy of Microbiology, Washington, DC

6. Hawkey PM, Jones AM (2009) The changing epidemiology of resistance. $J$ Antimicrob Chemother 64 Suppl 1: i3-10.

7. Lutful Kabir SM (2010) Avian colibacillosis and salmonellosis: a closer look at epidemiology, pathogenesis, diagnosis, control and public health concerns. Int J Environ Res Public Health 7: 89-114.

8. Casewell M, Friis C, Marco E, McMullin P, Phillips I (2003) The European ban on growth-promoting antibiotics and emerging consequences for human and animal health. J Antimicrob Chemother 52: 159-161.

9. Davies RH (2005) Pathogen populations on poultry farms, Food safety control in the poultry industry. Woodhead Publishing, Cambridge, United Kingdom.

10. Atterbury RJ, Van Bergen MA, Ortiz F, Lovell MA, Harris JA, et al. (2007) Bacteriophage therapy to reduce salmonella colonization of broiler chickens. Appl Environ Microbiol 73: 4543-4549

11. Hagens S, Loessner MJ (2007) Application of bacteriophages for detection and control of foodborne pathogens. Appl Microbiol Biotechnol 76: 513-519.

12. Matsuzaki S, Rashel M, Uchiyama J, Sakurai S, Ujihara T, et al. (2005) Bacteriophage therapy: a revitalized therapy against bacterial infectious diseases. J Infect Chemother 11: 211-219.

13. Li H, Ma ML, Xie HJ, Kong J (2012) Biosafety evaluation of bacteriophages for treatment of diarrhea due to intestinal pathogen Escherichia coli 3-2 infection of chickens. World J Microbiol Biotechnol 28: 1-6.

14. Parracho HM, Burrowes BH, Enright MC, McConville ML, Harper DR (2012) The role of regulated clinical trials in the development of bacteriophage therapeutics. J Mol Genet Med 6: 279-286.

15. Miller AJ, Eblen BS, Oser A, Burkhardt W 3rd (1998) Application and evaluation of male-specific bacteriophage as a process integrity or faecal contamination indicator in a pork slaughterhouse environment. J Appl Microbiol 85: 898-904. 
Citation: Bhensdadia DV, Bhimani HD, Nathani NM, Rawal CM, Koringa PG, et al. (2014) Isolation, Molecular Characterization and Insight into the Genome Sequence of E. Coli Bacteriophage ADB-2 from Poultry Fecal Sample. Next Generat Sequenc \& Applic 1: 101. doi:10.4172/24699853.1000101

16. Tanji Y, Mizoguchi K, Yoichi M, Morita M, Kijima N, et al. (2003) Seasonal change and fate of coliphages infected to Escherichia coli $\mathrm{O} 157: \mathrm{H} 7$ in a wastewater treatment plant. Water Res 37: 1136-1142.

17. Sinton LW, Finlay RK, Hannah DJ (1998) Distinguishing human from animal faecal contamination in water: a review. N. Z. J Mar Freshw Res 32:323-348.

18. Welkos S, Schreiber M, Baer H (1974) Identification of Salmonella with the O-1 bacteriophage. Appl Microbiol 28: 618-622.

19. Matsuzaki S, Rashel M, Uchiyama J, Sakurai S, Ujihara T, et al. (2005) Bacteriophage therapy: a revitalized therapy against bacterial infectious diseases. J Infect Chemother 11: 211-219.

20. Petty NK, Evans TJ, Fineran PC, Salmond GP (2007) Biotechnological exploitation of bacteriophage research. Trends Biotechnol 25: 7-15.

21. Skurnik M, Pajunen M, Kiljunen S (2007) Biotechnological challenges of phage therapy. Biotechnol Lett 29: 995-1003.

22. Skurnik M, Strauch E (2006) Phage therapy: facts and fiction. Int J Med Microbiol 296: 5-14.

23. Bielke LR, Higgins SE, Donoghue AM, Donoghue DJ, Hargis BM et al. (2007) Use of wide-host-range bacteriophages to reduce Salmonella on poultry products. Int. J. Poult. Sci 6: 754-757

24. Walker K (2006) Use of bacteriophages as novel food additives. Institute for Food Laws and Regulations, East Lansing, MI, USA.

25. Clark JR, March JB (2006) Bacteriophages and biotechnology: vaccines, gene therapy and antibacterials. Trends Biotechnol 24: 212-218.

26. Merril CR, Biswas B, Carlton R, Jensen NC, Creed GJ, et al. (1996) Longcirculating bacteriophage as antibacterial agents. Proc Natl Acad Sci U S A 93: 3188-3192.

27. Tinsley CR, Bille E, Nassif X (2006) Bacteriophages and pathogenicity: more than just providing a toxin? Microbes Infect 8: 1365-1371

28. Bielke L, Higgins S, Donoghue A, Donoghue D, Hargis BM (2007) Salmonella host range of bacteriophages that infect multiple genera. Poult Sci 86: 2536 2540

29. Krylov VN, Miller S, Rachel R, Biebl M, Pletneva EA, et al. (2006) [Ambivalent bacteriophages of different species active on Escherichia coli K12 and Salmonella sps. strains]. Genetika 42: 159-168.

30. Cappuccino JG, Sherman N (2004) Microbiology: A laboratory manual. 6th ed. Published by Pearson Educ. Singapore. Pvt. Ltd

31. Patil PS, Shedbalkar UU, Kalyani DC, Jadhav JP (2008) Biodegradation of Reactive Blue 59 by isolated bacterial consortium PMB11. J Ind Microbio Biotechnol 35: 1181-1190.

32. Dhanve RS, Kalyani DC, Phugare SS, Jadhav JP (2009) Coordinate action of exiguobacterial oxidoreductive enzymes in biodegradation of reactive yellow 84A dye. Biodegradation 20: 245-255

33. Aziz RK, Bartels D, Best AA, DeJongh M, Disz T, et al. (2008) The RAST Server: rapid annotations using subsystems technology. BMC Genomics 9: 75

34. Arlet G, Barrett TJ, Butaye P, Cloeckaert A, Mulvey MR, et al. (2006) Salmonella resistant to extended-spectrum cephalosporins: prevalence and epidemiology. Microbes Infect 8: 1945-1954.

35. Krylov VN, Miller S, Rachel R, Biebl M, Pletneva EA, et al. (2006) [Ambivalent bacteriophages of different species active on Escherichia coli K12 and Salmonella sps. strains]. Genetika 42: 159-168.

36. Langlois BE, Cromwell GL, Stahly TS, Dawson KA, Hays VW (1983) Antibiotic resistance of fecal coliforms after long-term withdrawal of therapeutic and subtherapeutic antibiotic use in a swine herd. Appl Environ Microbiol 46: 14331434.

37. Bonnet C, Diarrassouba F, Brousseau R, Masson L, Topp E, et al. (2009) Pathotype and antibiotic resistance gene distributions of Escherichia coli isolates from broiler chickens raised on antimicrobial-supplemented diets. App Environ Microbiol 75: 6955-6962.

38. Patel JB (2001) 16S rRNA gene sequencing for bacterial pathogen identification in the clinical laboratory. Mol Diagn 6: 313-321. 